\section{LITERARY ELEMENTS OF THE SĀSTRĀ LBAENG ${ }^{1}$}

\section{Santi Pakdeekam ${ }^{2}$}

\begin{abstract}
This article studies and analyzes the literary elements of the Sāstrā Lbaeng. The "Sāstrā Lbaeng" or "Lbaeng Story" is a genre of medieval Khmer literature, which was composed to provide pleasure and entertainment for its readers. The literary elements of the Sāstrā Lbaeng include nine elements: 1) The eulogies of the Sāstrā Lbaeng classified into three types based on the language used, namely, Pāli, Khmer and Pāli-Khmer eulogies; 2) The date of composition, written after the eulogy; 3) The poet's critical remarks about his work giving information about the author's name, identity and career; 4) The purpose of the Sāstrā Lbaeng as being mostly to maintain Buddhism; 5) The source in Buddhist literature which inspired the composition; 6) The opening and setting, which are influenced by the "Story of the present" of the Jātaka literature; ${ }^{3}$ 7) The content which reflects the influence of Buddhist concepts; 8) Prachum Jātaka or Samodhāna explains the identity of the characters during the life time of the Buddha; 9) Some of the Sāstrā Lbaeng
\end{abstract}

\footnotetext{
${ }^{1}$ I am grateful to Dr. Klairung Amratisha and Asst. Prof. Dr. Trisilpa Boonkhachorn for supervising my dissertation on which this paper is based.

${ }^{2}$ Lecturer, Department of Thai and Oriental Languages, Faculty of Humanities, Srinakharinwirot University, Thailand

${ }^{3}$ Some of the Sāstrā Lbaeng is not based on classical Buddhist literature but, nonetheless, the stories are introduced in the same way as those which are.
}

includes the aspiration of the poet or the audience to attain Nirvana. More than one topic may be included in the postscript.

\section{Introduction}

The "Sāstrā Lbaeng" or the "Lbaeng Story" is a genre of medieval Khmer literature composed between the $23^{\text {rd }}$ and $25^{\text {th }}$ Buddhist era to provide pleasure and entertainment for its audience. It is a combination of different forms of traditional Khmer poetry publicly recited by Buddhist monks, teachers or elders. Despite its popularity, only the content of the poems, not their literary form, has been studied.

The literary elements of the Sāstrā Lbaeng have characteristics, which can be found only in the Sāstrā Lbaeng, not in other genres of Khmer literature. These elements manifest clearly the influence of Jātaka literature on the Sāstrā Lbaeng especially in the parts of present state, the content or Atitavatthu and the conclusion (Prachum Jātaka or Samodhāna).

The literary elements of the Sāstrā Lbaeng, as roughly classified by Léang-Hap An, include three parts: an introduction, a body and an ending (Léang 1967: 217 - 218). In accordance with this ordering, the Sāstrā Lbaeng's form has been re-classified below in order to better clarify its literary elements, i.e. its conventions.

\section{Eulogy or Praṇāma Gātha}

A eulogy is usually written at the beginning of a literary work. It is a convention of the eulogy writing, found in classical Pāli literature, to show respect to deities, parents and teachers. It is considered a vital part of the Sāstrā Lbaeng because in addition to being a way 
of paying respect to holy artifacts, it is a

(Léang 1967: 264)

kind of literary competition. The eulogies of the Sāstrā Lbaeng are classified into three types, based on the languages used, namely, Pāli, Khmer and Pāli-Khmer eulogies.

\section{Pāli eulogy}

A Pāli eulogy is written to praise the Three Gems (Lord Buddha, Dharma and Sańgha), as well as parents, teachers and monarchs. The Pāli eulogies in Khmer poetry are considered ancient, as the first are found in the "Khyań Sańkh (Histoire de Khyang-Saing)". These eulogies are very different from those written in other works of Khmer literature in later periods in that they are written in the form of the "Brahma Gìti", that is ;

\section{subhamasaso tithimańgale \\ jayātireke ekachapañcekam \\ sakakukatha nakacabesakkham \\ ațtharojasam gurubāsuramā|}

(Institut Bouddhique 1961: 1)

May it be a good omen, at the beginning of Sakarāja 1651 (1729 A.D.), the year of dog, on Wednesday the $8^{\text {th }}$ day of the waxing moon.

Most of the Pāli eulogies in later periods are composed in the form of the "Kāka Gati", a kind of Khmer poetry, as in Lokanayapakar, which was written by Ukñā Vańs Sārabejñ (Nań).

$\begin{array}{ll}\text { ahamnamāa } & \text { misirasā } \\ \text { Susambuddham } & \text { anuttaro } \\ \text { sețthovaram } & \text { tilokānam } \\ \text { lokuttamo } & \\ \text { jitamāra } & \text { asamoa- } \\ \text { nantaññaņo } & \text { cabhagavā } \\ \text { canāyako } & \text { dasabalo } \\ \text { ca-atulam } & \end{array}$

I honour with head the Buddha, who is the incomparable, foremost and most excellent of the three worlds, super-mundane, conquering of evil, unequal, omniscient, auspicious, the master, the superpower and the matchless one.

Moreover, Pāli eulogies are also found in many other Sāstrā Lbaengs. They are sometimes accompanied by later Khmer renditions, as in the Brah Samuddaghosa (1818) by Ukñā Prājñā Dhipati (Kaew), the Chandaghāta (1886) by Chau Bañā Rājahakti, Chau Bañā Jamnit Ksatrī and Chau Baña Sri Añjit and the Māgha Mānab by Ukñā Uden.

\section{Khmer eulogy}

The eulogies in some Sāstrā Lbaengs are composed in Khmer, mostly in the form of the Kāka Gati among other poetic forms. The purpose of the eulogy is to pay respect to the Three Gems, praise the Lord Buddha, the Dharma and the Sangha, and worship the gods, kings, teachers, and parents. The Khmer eulogy in the Hańsa Yanta (Histoire de Hang-Yon) also includes a request for being blessed with an auspicious life (Institut Bouddhique 1998: $1-2)$.

The Buddhisen (Pouthisen) consists of a Khmer eulogy in the form of the Kāka Gati, in which, unlike other Sāstrā Lbaengs, only the eulogy for the Lord Buddha is found (Cedoreck 1986: 1). However, in Ciew Kun (Jāv Gun), the introductory part differs from the others in that the poet's love is mentioned first, followed by praise for the Three Gems and gratitude being shown towards his parents and teachers (Khing 2003: 70). The introductory extract follows: 
Since I first saw you, I have been thinking about you all day and all night, like the royal scholar who saw the lady affectionately staying close to the Garuda. The more I think about you, the more I feel confused and idle. Instead, I have asked my elder sister to remind me to compose the poem entitled Ciew Kun. (Khing 2003: 70)

\section{Pāli-Khmer eulogy}

The Pāli-Khmer eulogies, which are annexed to the Pāli ones, are translations from Pāli into Cambodian mixed with Pāli words, as in the Bhogakula Kumāra, in which the Pāli eulogy is translated into Khmer verses and mixed with Pāli words (Khing 2005: $1-3$ ).

\section{Date of composition}

Following the praise for the Three Gems, it is likely that Khmer poets probably provided the date and time of the composition in Pāli and Cambodian in order to reveal the initial date when the Sāstrā Lbaeng was composed. However, in some Sāstrā Lbaengs, only praise for the Three Gems, not the time of composition, is found. The first Sāstrā Lbaeng that includes the time of composition is the Khyań Sańkh (Histoire de Khyang-Saing), which states that it was composed on Wednesday of the $8^{\text {th }}$ waning moon day in the year of the Dog in 1729 (Institut Bouddhique 1961: 1). The time of composition is also found in other Sāstrā Lbaengs such as the Kākī by King Hariraksarāmā Issarādhipati (King Ańg Duang), in which he states that the poem was composed in 1815.

$\begin{array}{ll}\text { Buddhasāsanam } & \text { atikanta } \\ \text { mațthapañ } \tilde{\bar{a}} & \text { satisata } \\ \text { dvesahassā } & \text { mahāsakarājōa } \\ \text { ekasaptatrīsapta } & \end{array}$

(Institut Bouddhique 1997: 2)

In 2358 of the Buddhist Era, Mahāsakarāja 1737 (1851 A.D.).

\section{The poet's self-criticism}

The poet's self-criticism is a major part of the Sāstrā Lbaengs and is usually written immediately after the eulogy. This section consists of the poet's name, his/her profession and self-criticism. The poets often state that, due to their lack of literary skill, they may have made some mistakes in the assembly of the poems which comprise the overall beauty of the work. Therefore, the poems need correcting and improving. In some Sāstrā Lbaengs, like the Khyań Sańkh (Histoire de KhyangSaing), King Jaiya Jetthā IV's command to compose the poem is mentioned (Institut Bouddhique 1961: 4).

In the Krung Subhamitra by Ukñā Kosādhipati Kao (Oknha Kosadhipati $\mathrm{Kao}$ ), the poet mentions his name, profession and status, including the background and his aim of composing the poem as a pedagogy of the people. He also humbly states that since the poem may have been poorly composed therefore, any potential scholastic corrections are welcome in order to maintain the Buddhist religion (Oknha Kosadhipati Kao 1998: 3).

Another obvious and interesting sample of the poets and their self-criticism is the Maraņamātā, Brah Indappaññā (Uk), in which the poet's name and profession are mentioned. Also, the poet criticizes himself by humbly stating that, thanks to his low education, his poem may contain some mistakes and not sound sufficiently beautiful. He, therefore, calls upon scholars to correct and improve it, as in the following example. 
My old name was Uk, by which I was named and called only by my parents. I used that name for 12 years until I became ordained a novice and studied the Dharma. At the age of 20, I became ordained as a Buddhist monk. My master named me Indappañ̄̃a for an auspicious life. I stayed in the monkhood for another 20 years and composed this poem. If you find any mistakes in the poem, please correct them in order to maintain the Buddhist religion. (Institut Bouddhique 1963: 4)

However, in some of the Sāstrā Lbaeng, the poets' names and self-criticism are not mentioned, as in the Buddhisen (Pouthisen), the Hańsa Yanta (Histoire de Hang-Yon) and the Sańkha Silpajaya (Histoire de Saing Saing Selchey) published by the Institut Bouddhique.

\section{Objectives of composition}

The main objective of composing the Sāstrā Lbaeng was mostly to maintain and nourish the Buddhist religion. It was believed that the religion would last for 5,000 years before it declines. It is this belief that forced the poets to compose the Sāstrā Lbaeng in order to maintain the Buddhist religion as in the Kāki by King Hariraksarāmā Issarādhipati (King Ańg Duang). The poet states that his objective in composing this poem is to uphold Buddhism (Institut Bouddhique 1997: 1). This declaration demonstrates that the Khmer society of his period believed in Pañca Antradhāna. This was a practice also found in other Sāstrā Lbaengs such as the Bhogakulakumāra by Ukñā Vańs Sārabejñ (Nań), in which the poet states that his objective in composing the poem is to represent and uphold Buddhism. In the Maraņamātā by Brah Indappaññā (Uk), presented below, the poet clearly states that his objective in composing the poem is to maintain Buddhism until it is 5,000 years old.

Due to my strong determination to make merit, I stayed in the monkhood for 5,000 years. (Institut Bouddhique 1963: 4)

\section{Background of the story}

It is important that the background of the Sāstrā Lbaeng be mentioned. Most of the stories originate from Buddhist literature such as the Nipāta Jātaka and the Paññāsa Jataka. Some of the stories are believed to have been translated from Thai. One Sāstrā Lbaeng translated from the Paññāsa Jātaka was the Krung Subhamitra by Ukñā Kosādhipati Kao (Oknha Kosadhipati Kao). At the beginning of the poem, its source, the Paññāsa Jātaka, is mentioned.

The patriarch translated the poem from the Pañ̃āsa Jātaka. (Institut Bouddhique 1998: 2)

In the Buddhisen (Pouthisen), the story is said to have been translated from the Pāli version as existing in the Buddhist Țîkā.

The poem was translated from the Pāli version of the Buddhist Tīkā. (Cedoreck 1986: 1)

In some of the Sāstrā Lbaeng, the poets state that they have translated the poems from Thai, as in the Hańsa Yanta (Histoire de Hang-Yon), which was translated from Thai into Cambodian.

I translated the poem from Thai into Cambodian. (Institut Bouddhique 1998: 3) 


\section{Preface}

The preface and its present state are important literary elements of the Sāstrā Lbaeng since they are used to introduce the stories. Two kinds of introduction are used in the Sāstrā Lbaeng, namely,

\section{Present state}

Since most Sāstrā Lbaengs originated from the Jātaka, the introductory part was consequently influenced by the "Present State" of the Ațtha Kathā Jātaka or the Paññāsa Jātaka. However, some Sāstrā Lbaengs which did not directly originate from Buddhist literature introduce the stories in the same manner as those originating from Buddhist literature.

An example of a Sāstrā Lbaeng originating from Buddhist literature and introducing the stories with the present state is the Sabbhasiddhi (Histoire de Sabbhasiddhi), which originated from the Paññāsa Jātaka, by Meun Phakdei Aksar (Tan). The introductory part states that, at the time when the Lord Buddha stayed at Jetavana, all the Buddhist monks congregated and discussed his inestimable virtue. The Lord Buddha intuitively learned of this and declared to them that he had a lot of responsibilities not only at the present time but also when he was a Bodhisattva. The assembly of Buddhist monks asked him to preach after which the Lord Buddha preached on the Sabbhasiddhi Jātaka (Institut Bouddhique 1997: 3).

As for those not originating from Buddhist literature, the present state is used to introduce the story, as in the Bhogakula Kumāra by Ukñā Vańs Sārabejñ (Nań). The story starts with the present state, stating that, when the Lord Buddha stayed at Jetavana, the assembly of Buddhist monks talked about Devadatta, who planned unsuccessfully to kill the Lord Buddha. Devadatta was lured underground and killed by the Goddess of the Earth before being sent to the lowest hell in punishment. The Lord Buddha intuitively learned about the monks' discussion and, therefore, left his cell to declare that Devadatta had planned to kill him not only once at that present time but also many times in the past. After that, he stayed still for a while. Upon a request from the assembly of Buddhist monks to preach, the Lord Buddha complied with a semon on the Bhogakula Kumāra (Khing 2005: 4 7).

\section{Preface quoting the Lord Buddha's speech}

In some of the Sāstrā Lbaengs which originate from Buddhist literature and folktales, the story often starts with a preface quoting the Lord Buddha's speech in order that the audience will be convinced of the authenticity of the Lord Buddha's story, as in the Kākī, which originated from the Nipāta Jātaka, composed by King Hariraksarāmā Issarādhipati (King Ańg Duang). The preface states that it is a story about the Lord Buddha's previous life when "he was born a garuda dwelling in the castle on the cloud at the foot of Mount Sumeru."

The Kāka Gati poem was composed to describe the Lord Buddha's previous life when he was born a garuda dwelling in the castle on the cloud near Mount Sumeru. (Institut Bouddhique 1997: 3)

Some Sāstrā Lbaengs originate from folktales but claim to be translated or quoted from the Lord Buddha's speeches, as in the Hańsa Yanta (Histoire de HangYon), in which Suvaņna Kumāra 
consolidated his spiritual power before becoming the Lord Buddha.

In ancient times, Brah Suvañna Kumāra built up his spiritual power before becoming the Lord Buddha. Before this, he had been reborn and had traveled in the Cycle of life. However, he did not succeed in building up his power in this life. (Institut Bouddhique 1998: 3)

\section{Content or Atītavatthu}

The content or Atitavatthu is the most important component of a Sāstrā Lbaeng since it consists of the characters' behavior. According to Léang-Hap An, the second most important element is the content which is used to keep the story going. The poets use as many Magatha or Sanskrit words as possible in composing their poems (Léang 1967: 218). The stories show some influence of Buddhist ideology, especially the Sāstrā Lbaengs that originate from the Jătaka literature and its imitations.

\section{Conclusion (the Prachum Jātaka or Samodhāna)}

The Prachum Jātaka or Samodhāna, the conclusion of a Sāstrā Lbaeng, states which characters are derived from the time of the Lord Buddha. This practice is found both in the Sāstrā Lbaeng originating from the Jātaka and those imitations, in which the above term is clearly mentioned. For example, the term "Prachum Jātaka" is referred to in the Khyań Sańkh (Histoire de Khyang-Saing), the "Samodhāna" and the "Prachum Brah Jāti" in Buddhisen (Pouthisen), and the "Prachum Brah Jātaka" in Brah Sudhana (Histoire de Preah Sudhana). The conclusion reflects the belief and instruction of the Cycle of Karma in Buddhism, conveying to the audience the names of those who have been reborn and suffered from their previous deeds in the Buddhist period.

\section{The Prachum Jātaka or Samodhāna of the Sāstrā Lbaeng originating from the Jātaka literature}

\section{Those originating from the Nipāta Jātaka}

The $K \bar{a} k \bar{\imath}$ is one of the Sāstrā Lbaeng that originates from the Nipāta Jātaka, stating that Kākī was reborn as Ciñcā Māņavikā, whereas the Nățakuvera was reborn as Brah Moggallāna, King Brahmadatta was reborn as Brah Sāriputra, and the garuda was reborn as the Lord Buddha.

I would like to preach the sermon that Kāki was reborn as Ciñcā Mānavikā, Nāțakuvera was reborn as Brah Moggallāna, King Brahmadatta was reborn as Brah Säriputra and the garuda was reborn as the Lord Buddha. The poem was composed to teach all the creatures. (Institut Bouddhique 1997: 84)

\section{Those originating from the Paññāsa Jātaka}

The story of the Khyan Sańkh (Histoire de Khyang-Saing) is one of the Sāstrā Lbaengs that originates from the Pañnāsa Jătaka, describing rebirth in detail. In the poem, Chandā is reborn as Devadatta's wife, whereas Bandharassa is reborn as Baisākhā (Visākhā), King Sāmalarāja is reborn as Brah Ānanda, King Yasavī is reborn as King Suddhodana, Candadevī is reborn as Queen Sirimahāmāya, Racanā is reborn as Bimba, Suvaņņa Rājadhitā is reborn as Sri Sujātaka, Suvaņņa Rāja Kumāra is reborn as Rahul, Suvaņñadevī is reborn as Upalavaņna Therī and Prince 
Suvanna Sańkh is reborn as the Lord Buddha (Institut Bouddhique 1961: 255).

In Buddhisen (Pouthisen), which originates from the Pañnāsa Jātaka, the introduction states that Sandhamāra was reborn as Ciñcā Māņavikā, whereas the horse Mani Kaew Sura was reborn as Moggallāna Thera and Brah Tapasa was reborn as Ānanda Thera. Nothing about Buddhisen and Kańrī's rebirth is mentioned.

The preaching of Dharma Samodhāna revealed the Lord Buddha's previous life. The Tapasa was reborn Phra Ananda. (Cedoreck 1986: 122)

In addition to the Prachum Jātaka, the story of Brah Sudhana (Histoire de Preah Sudhana) mentions events after the Lord Buddha's sermons, when the audience had attained different levels of enlightenment from the lowest to Nirvana. The poems are written mainly in a combination of Cambodian mixed with Pāli words (Institut Bouddhique 1966: 249).

\section{The Prachum Jātaka or Samodhāna of the Sāstrā Lbaeng imitating the Jātaka}

The Hańsa Yanta (Histoire de Hang-Yon), which was one of the Jātaka imitations, mentions the same "Prachum Jātaka" as those in the Sāstrā Lbaeng originating from the Jātaka, stating that King Pañjāla was reborn as Devadatta, Sāgara Vāṇija was reborn as Moggallāna Thera, Samudra Sāgara was reborn as Sāriputra Thera, Mālā was reborn as Upalavaņña Therī, King Brahmadatta was reborn as Ānanda Thera, God Indra was reborn as Anuruddha Thera, Samrap Bhūpāla was reborn as Konāgama, Princess Paduma Kesara was reborn as Yasodhara, Prince Krissana Kumāra was reborn as Rāhula
Thera, King Āditya was reborn as King Suddhodana, Bimba was reborn as Queen Sirimahāmāya and Prince Suvaņņa Kumāra was reborn as the Lord Buddha at the time of writing.

The Lord Buddha gave a sermon about the Jätaka, which involves his previous lives. (Institut Bouddhique 1998: 234 - 237)

\section{Postscript}

The postscript, which follows the Prachum Jātaka, is also an important component of the Sāstrā Lbaeng. The Khmer poets prefer to write postscripts to mark the end of the poems, as in the Krung Subhamitra, in which the poet states that the Bodhisattava's story ends here (Oknha Kosadhipati Kao 1998: 95). In some of the Sāstrā Lbaeng, the background of the story is mentioned in the postscript, as in the Kākī, which has been translated from Thai into Cambodian as poems (Institut Bouddhique 1997: 84). In the Hańsa Yanta (Histoire de Hang-Yon), the background of the story is mentioned in the postscript, stating that it was translated from the Thai original (Institut Bouddhique 1998: 237). In some Sāstrā Lbaengs, the postscripts reveal the authors' intentions, the poets' wishes or requests for blessings, as in the Khyań Sańkh (Histoire de Khyang-Saing), which states that whoever happens to listen to the poem will surely appreciate the Dharma until his death, and the poet asks scholars to correct his poem if it does not sound pleasant (Institut Bouddhique 1961: 256).

In some Sāstrā Lbaengs, the postscripts include the purpose of composing the poems, the poet's self-criticism and a wish for attaining Nirvana. One example is the Sabbhasiddhi (Histoire de Sabbhasiddhi), in which the purpose for composing the 
poem is mentioned, defining its audience as those who are required to listen to the poem and requesting that it be taught to both males and females. Moreover, the poet critically forewarns that, since the poem has just been finished, it may not sound pleasant. He, therefore, fears that the poem may be disadvantageous in the future and asks the readers to forgive him as well as to correct the mistakes in the poem. Moreover, he wishes to attain Nirvana.

In the Hańsa Yanta (Histoire de HangYon), the purpose of composing the poem is mentioned, stating that it is the Lord Buddha's story at a time when he was accumulating his spiritual power. Therefore, whoever happens to listen to, learn, memorize, or inscribe the poem for the next generation's sake will be considered most auspicious and reliable. He will gain the Lord Buddha's intuition, be reborn in heaven, and attain Nirvana. Also, the background of the story is mentioned, stating that it is translated from the Thai original into Cambodian (Institut Bouddhique 1998: 237).

\section{Conclusion}

As analyzed above, the primary configuration of a Sāstrā Lbaeng consists of 9 literary elements, which are conventional and formulaic in the composition of any Sāstrā Lbaeng. The major literary elements of the Sāstrā Lbaeng are as follows.

The primary literary elements are the eulogy, which is used to show respect to teachers and may be written in Cambodian, Pāli or both Cambodian and Pāli. The time context or the date of the composition is written following the eulogy. The Khmer poets may insert the time or year of composition so that readers will reference the time when the poem was composed. In some Sāstrā Lbaengs, only praise for the Three Gems, not the date of composition, is mentioned. The poets and their self-criticism are used to inform us of the poets' names and their careers as well as to criticize themselves. The purpose of composing the poem is primarily to maintain Buddhism. The stories of the poems originate from elements of Buddhist literature such as the Nipāta Jātaka and Paññāsa Jātaka and some were translated from the Thai originals. The preface and the present state are influenced by the Jātaka literature. Some of the Sāstrā Lbaengs which do not originate from Buddhist literature introduce the stories in the same way as those originating from Buddhist literature. Some of the poems that originate from Buddhist literature and folktales are likely to state the preface prior to the introduction, claiming that they originate from the Lord Buddha's speech.

The middle component is the content or the flashback, which is considered the most important contextual component of the poem, providing a description of the characters' behavior. It reflects the influence of Buddhist concepts, especially in those Sāstrā Lbaengs that directly originate from Jātaka literature and other Jātaka imitations.

The final component is the Prachum Jātaka or Samodhāna, which concludes the story of the poem and describes those who were reborn during the Buddhist period. This practice also belongs to those Sāstrā Lbaengs originating from the Jātaka and Jātaka imitations. The postscript may only mark the end of the story or reveal its background and the purpose of composing the poem, including a wish for the poet or 
the audience to attain Nirvana. More than one topic may be included in the postscript.

\section{References}

Cedoreck. 1986. Pouthisen (Buddhisen). Paris: Cedoreck.

Khing Hoc Dy. 2003. Anthologie de la Littérature Khmère du XIXème Siècle. Phnom-Penh: Angkor.

---. 2005. Bhogakula Kumāra. PhnomPenh: Angkor.

Institut Bouddhique. 1961. Histoire de Khyang-Saing. Phnom-Penh: Institut Bouddhique.

---. 1998. Histoire de Hang-Yon. PhnomPenh: Institut Bouddhique.

---. 1963. Histoire de Preah Sudhana. Phnom-Penh: Institut Bouddhique.

---. 1997. Histoire de Sabbhasiddhi. Phnom-Penh: Institut Bouddhique.

---. 1997. Rioeń Kākī. Phnom-Penh: Institut Bouddhique.

---. 1963. Rioeń Marañamātā. PhnomPenh: Institut Bouddhique.

Jacob, Judith M.. 1996. The Traditional Literature of Cambodia. New York: Oxford University press.

Léang-Háp An. 1967. Histoire de la Littérature Khmère (du ler siècle à 1859). Phnom-Penh: Kim Eng.
Oknha Kosadhipati Kao. 1998. Krung Subhamitra. Phnom-Penh: Institut Bouddhique. 